\title{
Kontribusi Kepemimpinan Kepala Sekolah dan Iklim Kerja Terhadap Kinerja Guru
}

\section{M. Dwi Angga *, I K. Ngurah Wiyasa'}

\author{
${ }^{1}$ Prodi Pendidikan Guru Sekolah Dasar, Universitas Pendidikan Ganesha, \\ Singaraja, Indonesia, \\ *e-mail: imadedwiangga25@undiksha.ac.id
}

\begin{abstract}
Abstrak
Menurunya kualitas kinerja guru sangat mempengaruhi proses pembelajaran. Salah satu faktor yang dapat mempengaruhi kinerja guru adalah kepemimpinan kepala sekolah dan iklim kerja. Penelitian ini bertujuan untuk mengetahui kontribusi kepemimpinan kepala sekolah dan iklim kerja terhadap kinerja guru. Penelitian ini berjenis penelitian ex-post facto dengan jumlah populasi sekaligus menjadi sampel sebanyak 34 orang. Metode pengumpulan data pada penelitian ini menggunakan kuesioner kinerja guru, kepemimpinan kepala sekolah dan iklim kerja. Data yang diperoleh dianalisis menggunakan teknik analisis statistik inferensial melalui uji-regresi sederhana dan uji-regresi ganda. Sebelum dilakukanya uji-regresi sederhana dan ujiregresi ganda dilakukan terlebih dahulu uji prasyarat yaitu, uji normalitas, uji linieritas, uji multikolonieritas, dan uji heteroskedastisitas. Hasil penelitian yaitu, 1) Kepemimpinan kepala sekolah berkontribusi sebesar $43,95 \%$ terhadap kinerja guru, 2) Iklim kerja berkontribusi sebesar 33,49\% terhadap kinerja guru, 3) Kepemimpinan kepala sekolah dan iklim kerja berkontribusi terhadap kinerja guru dengan kontribusi sebesar $77,44 \%$. Jadi, kinerja guru dipengaruhi oleh kepemimpinan kepala sekolah dan iklim tempat kerja.
\end{abstract}

Kata kunci: kepemimpinan, iklim kerja, kinerja guru

\begin{abstract}
The decline in the quality of teacher performance greatly affects the learning process. One of the factors that can affect teacher performance is the principal's leadership and work climate. This study aims to determine the contribution of principal leadership and work climate to teacher performance. This research is an ex-post facto study with a total population of 34 people as a sample. The data collection method in this study used a questionnaire on teacher performance, principal leadership and work climate. The data obtained were analyzed using inferential statistical analysis techniques through simple regression test and multiple regression test. Before the simple regression test and multiple regression test are carried out, the prerequisite tests are first carried out, namely, normality test, linearity test, multicolonierity test, and heteroscedasticity test. The results of the study were, 1) Principal leadership contributed $43,95 \%$ to teacher performance, 2) Work climate contributed $33,49 \%$ to teacher performance, 3) Principal leadership and work climate contributed to teacher performance with a contribution of $77,44 \%$. So, than that shows that together the leadership of the principal and the work climate contribute to teacher performance.
\end{abstract}

Keywords: leadership, work climate, teacher perfomance

\section{Pendahuluan}

Pembelajaran adalah proses interaksi antara peserta didik dan sumber belajar. Pembelajaran yang berkualitas akan mempu menghujudkan tujuan pembelajaran dan tentunya akan berdampak terhadap tujuan pendidikan nasional. Keberhasilan pembelajaran tidak terlepas dari kinerja guru. Kinerja guru dalam hal ini berkaitan dengan kemampuan guru dalam menyelesaikan tugas dan tanggungjawabnya dalam merancang, melaksanakan dan mengevaluasi pembelajaran (Sodik et al., 2019; Subandi, 2018; Wijania, 2017). Kualitas kinerja guru akan mempengaruhi kualitas pembelajaran yang nantinya akan mempengaruhi prestasi siswa (Junianto \& Wagiran, 2013). Kualitas kinerja 
guru baik terbentuk jika didukung oleh beberapa faktor. Baik itu faktor dari dalam diri guru ataupun faktor luar diri guru. Faktor yang mempengaruhi kinerja guru yang berasal dari dalam diri guru antara lain motivasi, kompetensi profesional, pedagogi, social dan kenyamanan dalam melakukan tugas dan tanggung jawabnya (Hartini et al., 2021; Yustiyawan et al., 2016). Kenyaman yang dirasakan oleh guru berkaitan dengan iklim kerja dan kepemimpinan kepala sekolah. Kepemimpinan kepala sekolah yang baik akan mampu menimbulkan motivasi guru dalam menyelesaikan tugas dan tanggungjawabnya.

Namun pada kenyataanya kinerja guru masih belum optimal dikarenakan faktorfaktor tersebut kurang diperhatikan. Dilapangan hubungan komunikasi guru dengan kepala sekolah masih belum optimal. Sehingga hal tersebut dapat mempengaruhi guru untuk melaksanakan tugasnya. Kerja sama antara guru dengan kepala sekolah seharusnya dijaga dengan baik, karena hal tersebut akan mempengaruhi kinerja guru. Pemimpin harus sentiasa memberikan pembinaan dalam mempengaruhi tenaga kependidikan di sekolah (Sanders et al., 2017). Sebagai kepala sekolah harus mampu dalam halnya mengambil keputusan yang cepat dan tepat, dapat memberikan pengawasan dan petunjuk. Kepemimpinan merupakan suatu kegiatan dalam mempengaruhi orang lain untuk mau bekerja dan mencapai tujuan bersama yang telah ditentukan (Rahayu, 2017). Kepemimpinan kepala sekolah dapat menentukan mutu suatu sekolah itu sendiri. Faktor yang berhubungan dengan kepemimpinan kepala sekolah adalah iklim kerja. Iklim kerja adalah suasana yang terdapat dalam suatu sekolah yang menggambarkan hubungan yang harmonis antar warga sekolah. Iklim kerja merupakan ide dalam merefleksikan kekuatan nilai-nilai, norma, sikap, tingkah laku dan perasaan anggota terhadap suatu sistem (Sugiarta et al., 2018). Iklim yang positif dirasakan oleh tenaga pendidik maka akan meningkatkan daya tahan seorang pendidik dalam menghadapi tekanan dalam melaksanakan tugasnya (Jati, 2017). Di lapangan faktor iklim kerja sekolah seringkali tidak diperhatikan oleh warga sekolah. Terjadinya hubungan yang harmonis antar warga sekolah pastinya akan membuat keadaan dimana warga sekolah khususnya guru merasa nyaman keadaan yang nyaman saat bekerja. Jika guru nyaman saar bekerja maka akan mempengaruhi antusiasme guru tersebut dalam melaksanakan tugas dan tanggung jawabnya. Jika kinerja guru optimal seharusnya akan mempengaruhi tujan yang ingin dicapai khususnya tujan pendidikan. Jadi, kinerja guru dipengaruhi oleh kepemimpinan kepala sekolah dan iklim kerja.

$\mathrm{Hal}$ ini sesuai dengan hasil penelitian yang dilakukan oleh Wijania, (2017) menyatakan bahwa faktor yang dapat mempengaruhi kinerja guru adalah kepemimpinan kepala sekolah. Penelitian yang dilakukan oleh Jamma, (2016) menyatakan bahwa kepemimpinan kepala sekolah sangat berhubungan dengan kinerja guru. Silalahi et al., (2016) menyatakan bahwa semakin tinggi iklim organisasi maka kinerja gurupun akan meningkat. Pramesti \& Muhyadi, (2018) menyatakan bahwa Supervisi kepala sekolah, motivasi kerja, iklim kerja guru dan status sosial ekonomi secara bersama-sama berpengaruh terhadap kinerja guru. Ramadoni et al., (2016) menyatakan bahwa hubungan yang sinergis antara kepala sekolah dengan guru, guru dengan guru serta kerjasama guru untuk memudahkan dalam meningkatkan semangat kinerja. Setiyati, (2016) menyatakan bahwa ada pengaruh yang positif dan signifikan antara kepemimpinan kepala sekolah, motivasi kerja, budaya sekolah terhadap kinerja guru. Jadi, dengan adanya faktor kepemimpinan kepala sekolah dan iklim kerja yang baik akan mempengaruhi kinerja guru. Untuk mengetahui seberapa pengaruh kepemimpinan kepala sekolah dan iklim kerja terhadap kinerja guru maka penelitian yang bertujuan untuk mengetahui kontribusi kepemimpinan kepala sekolah dan iklim kerja terhadap kinerja guru di SD Gugus II Tegallalang Tahun Ajaran 2020/2021. Dengan mengetahui kulitas kinerja guru dan faktor yang mempengaruhi kinerja guru, akan memberikan kajian pengetahuan tentang kondisi kinerja guru saat ini dan dapat mencari solusi yang tepat untuk mengatasi masalah yang yang berkaitan dengan kinerja guru. 


\section{Metode}

Dalam penelitian ini bertujuan untuk mengetahui kontribusi kepemimpinan kepala sekolah dan iklim kerja terhadap kinerja guru, tanpa adanya kesengajaan memberikan perlakuan untuk menimbulkan variabel yang ingin diteliti sehingga menggunakan rancangan "ex post facto" dengan jenis studi korelasi. Ex post facto yaitu penelitian yang dilakukan setelah adanya kejadian sesuai fakta (Sukardi, 2012). Dalam penelitian ini memiliki 1 variabel terikat dan 2 variabel bebas. Variabel terikat dalam penelitian ini ialah kinerja guru $(Y)$, sedanangkan variable bebanya adalah kepemimpinan kepala sekolah $\left(\mathrm{X}_{1}\right)$ dan iklim kerja $\left(\mathrm{X}_{2}\right)$.

Populasi yang sekaligus menjadi sampel dalam penelitian ini yaitu guru PNS di SD Gugus II Tegallalang berjumlah 34 orang. Teknik pengambilan sampel dalam penelitian ini menggunakan sampling total, yaitu semua anggota populasi digunakan sebagai sampel. Pada penelitian ini, data dikumpulkan melalui teknik non tes yaitu kuesioner. kuesioner digunakan untuk mengumpulkan data mengenai kinerja guru, data kepemimpinan kepala sekolah, dan data iklim kerja.

Instrument yang digunakan dalam penelitian ini melewati uji coba instrumen terlebih dahulu. Hal tersebut dilakukan untuk mengetahui validitas dan reliabilitas instrumen itu sendiri. Uji pertama yang dilakukan adalah uji validitas konstruk, dimana menggunakan 2 ahli materi untukmenguji kelayakan instrumen. Kemudian uji validitas butir, dimana hasil dari pengujian ini yaitu dari 35 butir soal kuisioner kinerja guru jumlah butir yang valid adalah 27 butir pernyataan, kuisioner kepemimpinan kepala sekolah jumlah butir yang valid adalah 26 butir pernyataan, dan kuisioner iklim kerja jumlah butir yang valid adalah 28 butir pernyataan. Selanjutnya hasil uji reliabilitas kuisioner kinerja guru $=0,956$, kuisioner kepemimpinan kepala sekolah $=0,926$, dan kuisioner iklim kerja $=$ 0,961 sehingga ketiga instrument tergolong kategori tinggi. Berikut adalah kisi-kisi instrument yang digunakan tertera pada table 1, 2 dan 3 di bawah ini.

Table 1. Kisi-Kisi Instrumen Kinerja Guru

\begin{tabular}{|c|c|c|c|c|c|}
\hline \multirow{2}{*}{$\begin{array}{l}\text { Variabel } \\
\text { Penelitian }\end{array}$} & \multirow[b]{2}{*}{ Indikator } & \multirow[b]{2}{*}{ Dimensi } & \multicolumn{2}{|c|}{ No Item } & \multirow[b]{2}{*}{ Jm } \\
\hline & & & $(+)$ & $(-)$ & \\
\hline \multirow[t]{11}{*}{$\begin{array}{l}\text { Kinerja } \\
\text { Guru }\end{array}$} & Pedagogik & $\begin{array}{l}\text { 1. Mengenal karakteristik } \\
\text { peserta didik }\end{array}$ & $\begin{array}{c}1,2 \\
3\end{array}$ & 4 & 4 \\
\hline & & $\begin{array}{l}\text { 2. Menguasai teori-teori belajar } \\
\text { dan prinsip pembelajaran }\end{array}$ & 5,6 & - & 2 \\
\hline & & 3. Pengembangan kurikulum & 7,8 & 9,10 & 4 \\
\hline & & $\begin{array}{l}\text { 4. Memahami dan } \\
\text { mengembangkan potensi }\end{array}$ & $\begin{array}{l}11 \\
12\end{array}$ & - & 2 \\
\hline & & $\begin{array}{l}\text { 5. Komunikasi dengan peserta } \\
\text { didik }\end{array}$ & $\begin{array}{r}13 \\
14\end{array}$ & 15 & 3 \\
\hline & & $\begin{array}{l}\text { 6. Penilaian hasil belajar dan } \\
\text { evaluasi }\end{array}$ & $\begin{array}{l}16 \\
17 \\
19\end{array}$ & 18 & 4 \\
\hline & Kepribadian & $\begin{array}{l}\text { 1. Bertindak sesuai dengan } \\
\text { norma agama, hukum, sosial, } \\
\text { dan kebudayaan nasional } \\
\text { indonesia }\end{array}$ & $\begin{array}{l}20 \\
21\end{array}$ & - & 2 \\
\hline & & $\begin{array}{l}\text { 2. Menunjukan pribadi yang } \\
\text { dewasa dan teladan }\end{array}$ & 22 & - & 1 \\
\hline & & $\begin{array}{l}\text { 3. Etos kerja dan tanggung } \\
\text { jawab yang tinggi dan rasa } \\
\text { bangga menjadi guru }\end{array}$ & $\begin{array}{l}23 \\
24 \\
25\end{array}$ & 26 & 4 \\
\hline & Sosial & $\begin{array}{l}\text { 1. Bersifat obyektif serta tidak } \\
\text { deskriminatif }\end{array}$ & 27 & 28 & 2 \\
\hline & & 2. Komunikasi dengan sesama & 29 & 32 & 4 \\
\hline
\end{tabular}




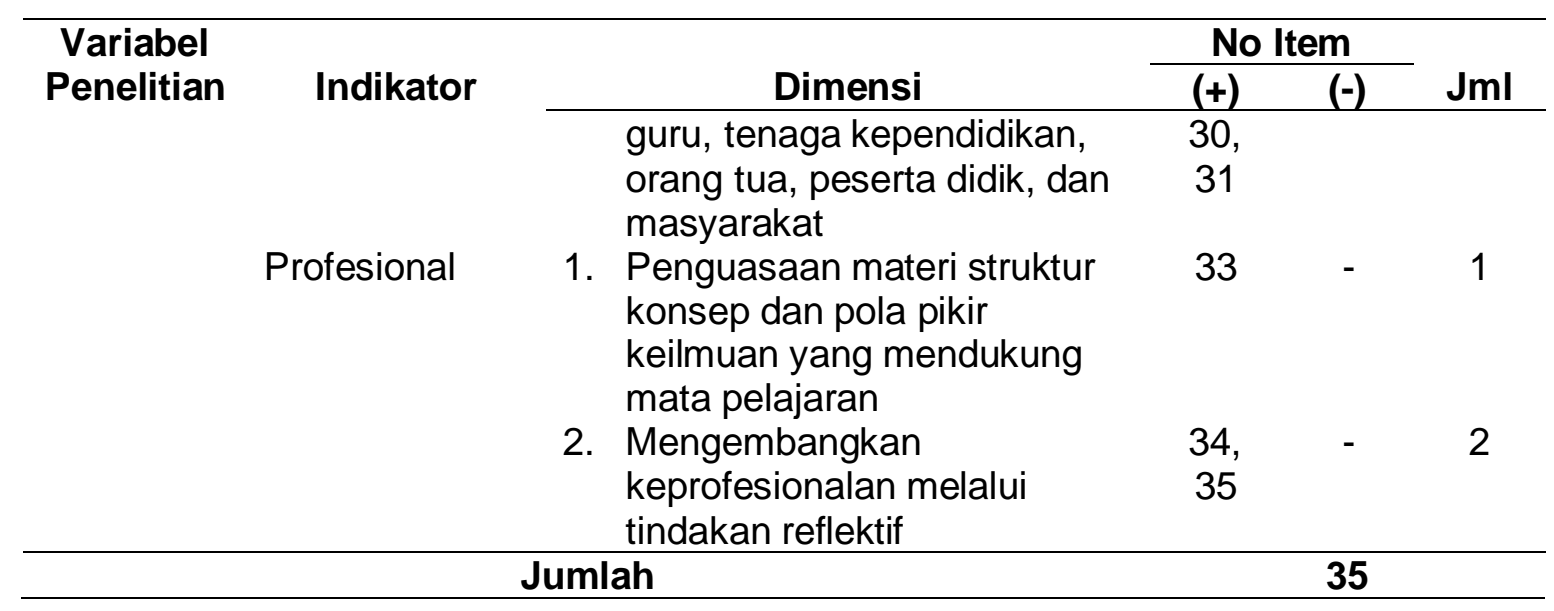

Tabel 2. Kisi-Kisi Instrumen Kepemimpinan Kepala Sekolah

\begin{tabular}{|c|c|c|c|c|c|}
\hline \multirow{2}{*}{ Variabel } & \multirow[t]{2}{*}{ Indikator } & \multirow[t]{2}{*}{ Dimensi } & \multicolumn{2}{|c|}{ No Item } & \multirow[t]{2}{*}{ Jml } \\
\hline & & & $(+)$ & $(-)$ & \\
\hline \multirow[t]{15}{*}{$\begin{array}{l}\text { Kepemimpinan } \\
\text { Kepala Sekolah }\end{array}$} & \multirow[t]{4}{*}{$\begin{array}{l}\text { Fungsi } \\
\text { Inovator }\end{array}$} & $\begin{array}{l}\text { 1. Pemrakarsa } \\
\text { pembaharuan (agen of } \\
\text { innovation) dalam KMB }\end{array}$ & 1,2 & 3 & 3 \\
\hline & & $\begin{array}{l}\text { 2. Pembaharuan dalam } \\
\text { pembinaan guru }\end{array}$ & 4,5 & & 2 \\
\hline & & $\begin{array}{l}\text { 3. Pembaharuan dalam } \\
\text { kegiatan ekstrakulikuler }\end{array}$ & 6 & 7 & 2 \\
\hline & & $\begin{array}{l}\text { 4. Menggali sumber daya } \\
\text { bersama komite } \\
\text { sekolah }\end{array}$ & 8,9 & & 2 \\
\hline & \multirow[t]{7}{*}{$\begin{array}{l}\text { Fungsi } \\
\text { Motivator }\end{array}$} & 1. Kerjasama kemitraan & $\begin{array}{l}10 \\
11\end{array}$ & & 2 \\
\hline & & 2. Keteladanan & $\begin{array}{l}12 \\
14\end{array}$ & 13 & 3 \\
\hline & & $\begin{array}{l}\text { 3. Demokratis dan } \\
\text { transparan }\end{array}$ & 15 & 16 & 2 \\
\hline & & $\begin{array}{l}\text { 4. Penataan lingkungan } \\
\text { kerja }\end{array}$ & 17 & 18 & 2 \\
\hline & & $\begin{array}{l}\text { 5. Suasana kerja yang } \\
\text { kondusif }\end{array}$ & 19 & 20 & 2 \\
\hline & & $\begin{array}{l}\text { 6. Pemberian } \\
\text { penghargaan }\end{array}$ & $\begin{array}{l}21 \\
22 \\
24\end{array}$ & 23 & 4 \\
\hline & & 7. Penerapan Sangsi & 26 & 25 & 2 \\
\hline & \multirow[t]{3}{*}{$\begin{array}{l}\text { Fungsi } \\
\text { Supervisor }\end{array}$} & $\begin{array}{l}\text { 1. Menyusun program } \\
\text { supervisi pengajaran }\end{array}$ & 28 & 27 & 2 \\
\hline & & $\begin{array}{l}\text { 2. Melaksanakan program } \\
\text { supervisi pengajaran }\end{array}$ & 30 & 29 & 2 \\
\hline & & $\begin{array}{l}\text { 3. Memanfaatkan hasil } \\
\text { supervisi pengajaran }\end{array}$ & $\begin{array}{l}31 \\
32\end{array}$ & $\begin{array}{l}33, \\
34, \\
35\end{array}$ & 5 \\
\hline & \multicolumn{2}{|c|}{ Jumlah } & & 35 & \\
\hline
\end{tabular}

Tabel 3. Kisi-Kisi Instrumen Iklim Kerja

\begin{tabular}{llllll}
\hline Variabel & \multicolumn{2}{c}{ Indikator } & \multicolumn{2}{c}{ Dimensi } & \multicolumn{2}{c}{ No Item } & Jml \\
\cline { 3 - 4 } & & & $(+)$ & $(-)$ & \\
\hline Iklim & Fisik & 1. & Keamanan & 1,2 & 2
\end{tabular}




\begin{tabular}{|c|c|c|c|c|c|}
\hline \multirow[t]{2}{*}{ Variabel } & \multirow[t]{2}{*}{ Indikator } & \multirow[t]{2}{*}{ Dimensi } & \multicolumn{2}{|c|}{ No Item } & \multirow[t]{2}{*}{ Jml } \\
\hline & & & $(+)$ & $(-)$ & \\
\hline \multirow[t]{11}{*}{ Kerja } & & 2. Ketertiban & $3,4,5$ & & 3 \\
\hline & & 3. Kebersihan & 7 & 6 & 2 \\
\hline & & 4. Kesehatan & 8 & 9 & 2 \\
\hline & & 5. Kerindangan & 10,11 & & 2 \\
\hline & & 6. Keindahan & $\begin{array}{c}12 \\
13,15\end{array}$ & 14 & 4 \\
\hline & & 7. Kesejukan & 17,18 & 16 & 3 \\
\hline & Psikologis & 1. Tidak ada saling curiga & 19,20 & 21 & 3 \\
\hline & & 2. Keterbukaan & $\begin{array}{c}22, \\
23,25\end{array}$ & $\begin{array}{l}24, \\
26\end{array}$ & 5 \\
\hline & & 3. Keakraban & $\begin{array}{c}27 \\
28,29\end{array}$ & & 3 \\
\hline & & 4. Kekeluargaan & $\begin{array}{c}30 \\
32,33\end{array}$ & 31 & 4 \\
\hline & & 5. Suasana ceria & 34,35 & & \\
\hline
\end{tabular}

Dalam penelitian ini, data yang diperoleh dianalisis menggunakan metode analisis statistik inferensial. Dalam pengujian hipotesis menggunakan statistik inferensial yaitu uji regresi linier ganda. Uji prasyarat analisis dilakukan sebelum melakukan uji hipotesis yang meliputi uji normalitas, uji linieritas, uji multikolinieritas, dan uji heteroskedastisitas.

Setelah memenuhi uji prasyarat, data dapat dianalisis dengan analisis korelasi dan regresi. Pengujian hipotesis dianalisis menggunakan analisis regresi berganda. Uji hipotesis dilakukan dengan menggunakan taraf signifikansi 5\%. Apabila nilai thitung > ttabel berarti hipotesis diterima, dan sebaliknya jika thitung $<$ ttabel berarti hipotesis ditolak. Pengujian hipotesis dilakukan dengan bantuan SPSS 24.0 for windows.

\section{Hasil dan Pembahasan}

Pada penelitian ini, data diperoleh dari hasil kuesioner kinerja guru, kepemimpinan kepala sekolah, dan iklim kerja dalam kelompok guru PNS di SD Gugus II Tegalallang yang dijadikan sampel dalam penelitian ini. Rangkuman analisis deskripsi data hasil penelitian yang diperoleh disajikan pada Tabel 4 berikut.

Tabel 4. Tabel Rekapitulasi Hasil Perhitungan Kinerja Guru, Kepemimpinan Kepala Sekolah, dan Iklim Kerja

\begin{tabular}{cccc}
\hline Statistik & Kinerja Guru & $\begin{array}{c}\text { Kepemimpinan Kepala } \\
\text { Sekolah }\end{array}$ & Iklim Kerja \\
\hline N & 34 & 34 & 34 \\
Rata - rata & & 110,32 & 110,65 \\
(Mean) & 98,82 & 6,83 & 8,64 \\
Standar & & & \\
Deviasi & 8,20 & 46,71 & 74,66 \\
Varian & 67,30 & 124 & 127 \\
Skor & 118 & & 96 \\
Maksimum & & 101 & \\
Skor Minimum & 84 & & \\
\hline
\end{tabular}

Hasil perhitungan menunjukkan rata-rata skor kinerja guru sebesar 98,82, rata-rata skor kepemimpinan kepala sekolah 110,32 dan rata-rata skor iklim kerja 110,65. Dalam menggolongkan tinggi rendahnya kualitas variabel, maka skor tiap-tiap variabel dikonversikan dengan menggunakan kriteria rata-rata ideal (Mi) dan standar deviasi ideal (SDi). Hasil konversi skor variabel menunjukkan rata-rata kinerja guru, kepemimpinan kepala sekolah, dan iklim kerja termasuk kategori sangat baik. 
Uji prasyarat pada penelitian ini menunjukkan data yang berdistribusi normal. Data kepemimpinan kepala sekolah terhadap kinerja guru memiliki hubungan yang linier dan data iklim kerja terhadap kinerja guru menunjukkan hubungan yang linier. Kemudian tidak terjadi masalah multikolinieritas dan masalah heterokedastisitas pada data. Selanjutnya jika uji prasyarat dapat terpenuhi, maka uji hipotesis dapat dilakukan. Pengujian uji hipotesis dilakukan menggunakan analisis regresi ganda.

Pengujian hipotesis pada penelitian ini menggunakan uji regresi berganda. Dalam penelitian ini, hipotesisi yang diujikan adalah $\mathrm{HO}$ yaitu, (1) tidak terdapat kontribusi yang signifikan antara kepemimpinan kepala sekolah terhadap kinerja guru di SD Gugus II Tegallalang Tahun Ajaran 2020/2021, (2) tidak terdapat kontribusi yang signifikan antara iklim kerja terhadap kinerja guru di SD Gugus II Tegallalang Tahun Ajaran 2020/2021, dan (3) tidak terdapat kontribusi yang signifikan antara kepemimpinan kepala sekolah dan iklim kerja terhadap kinerja guru di SD Gugus II Tegallalang Tahun Ajaran 2020/2021.

Hubungan antara kepemimpinan kepala sekolah dan iklim kerja terhadap kinerja guru ditunjukan pada koefisien korelasi rhitung. Nilai rhitung yang digunakan dalam penelitian ini adalah sebesar 0,88 dengan nilai rtabel adalah sebesar 0,388. Karena nilai rhitung > rtabel, maka koefisien ini signifikan yang memiliki arti bahwa kepemimpinan kepala sekolah dan iklim kerja memiliki hubungan yang positif terhadap kinerja guru. Dapat dilihat dari hasil pengujian berikut. Nilai koefisien determinasi yang dihasilkan oleh penelitian ini adalah sebesar $77,44 \%$ yang disebabkan oleh variabel kepemimpinan kepala sekolah dan iklim kerja. Sedangkan sebanyak 22,56\% disebabkan dari luar variabel yang diteliti. Selanjutnya dilanjutkan dengan pengujian yang bertujuan untuk mengetahui bobot sumbangan efektif (SE) dari masing-masing variabel bebas kepemimpinan kepala sekolah (X1) dan iklim kerja (X2) terhadap variabel terikat kinerja guru $(Y)$. Dari hasil pengujian yang dilakukan dapat disimpulkan sumbangan secara bersama-sama variabel kepemimpinan kepala sekolah menyumbang sebesar $\mathbf{4 3 , 9 5 \%}$ dan variabel iklim kerja menyumbang sebesar $33,49 \%$ terhadap variabel kinerja guru. Maka sumbangan efektif dari kedua variabel terhadap kinerja guru adalah $\mathbf{7 7 , 4 4 \%}$ dan sebesar $22,56 \%$ dari luar variabel yang diteliti.

Temuan pertama, berdasarkan taraf signifikansi $5 \%$ ternyata hipotesis nol $\left(\mathrm{H}_{0}\right)$ yang menyatakan bahwa tidak terdapat kontribusi yang signifikan antara kepemimpinan kepala sekolah terhadap kinerja guru di SD Gugus II Tegallalang tahun ajaran 2020/2021 ditolak dan hipotesis alternatif $\left(\mathrm{H}_{1}\right)$ dinyatakan diterima. Dengan demikian dapat ditarik simpulan bahwa terdapat kontribusi yang signifikan antara kepemimpinan kepala sekolah terhadap kinerja guru di SD Gugus II Tegallalang tahun ajaran 2020/2021. Koefisien korelasi variabel kepemimpinan kepala sekolah terhadap kinerja guru adalah sebesar 0,86 . Sumbangan efektif (SE) variabel kepemimpinan kepala sekolah terhadap kinerja adalah sebesar 43,95\%. Kepemimpinan kepala sekolah dapat mempengaruhi kinerja guru karena kepala sekolahlah yang mengarahkan bawahan untuk mencapai tujuan yang telah ditetapkan dengan cara memotivasi, mengambil keputusan, mengawasi, mengarahkan, mempengaruhi, dan cara lain yang dapat dilakukan agar bawahan tetap melaksanakan tugas dan tanggung jawabnya. Menurut Hardono (2017), kepemimpianan adalah seserang yang memiliki kemampuan dalam mengarahkan seseorang dalam mencapai sasaran. Dimana seorang kepala sekolah harus menjadi cerminan atau tauladan bagi seorang guru. Suksesnya pembelajaran di sekolah sangat dipengaruhi oleh kepemimpinan kepala sekolah (Astuti, 2017). Kepemimpinan adalah suatu proses sosial yang dengan sengaja dilakukan oleh seseorang untuk mempengaruhi orang lain untuk menata prilaku mereka (Wote \& Patalatu, 2019). Diperkuat dari penelitian sebelumnya oleh Wijania (2017), menyatakan faktor yang dapat mempengaruhi kinerja guru adalah kepemimpinan kepala sekolah. Dimana kepemimpinan kepala sekolah memberikan kontribusi yang signifikan dengan kinerja guru dengan koefisien kontribusi sebesar 0,572, determinasi sebesar $32,70 \%$. Maka dapat disimpulkan bahwa kepemimpinan kepala sekolah dapat berpengruh terhadap kinerja guru. 
Temuan kedua, berdasarkan taraf signifikansi 5\% ternyata hipotesis nol $\left(\mathrm{H}_{0}\right)$ yang menyatakan bahwa tidak terdapat kontribusi yang signifikan antara iklim kerja terhadap kinerja guru di SD Gugus II Tegallalang tahun ajaran 2020/2021 ditolak dan hipotesis alternatif $\left(\mathrm{H}_{1}\right)$ dinyatakan diterima. Dengan demikian maka dapat ditarik simpulan bahwa terdapat kontribusi yang signifikan antara iklim kerja terhadap kinerja guru di SD Gugus II Tegallalang tahun ajaran 2020/2021. Koefisien korelasi variabel iklim kerja terhadap kinerja guru adalah sebesar 0,85 . Sumbangan efektif (SE) variabel iklim kerja terhadap kinerja guru adalah sebesar 33,49\%. Menurut Fitri (dalam Sugiarta, 2018) mengemukakan bahwa, iklim kerja merupakan ide dalam merefleksikan kekuatan nilainilai, norma, sikap, tingkah laku dan perasaan anggota terhadap suatu sistem. Iklim kerja dapat mempengaruhi kinerja guru karena iklim kerja sekolah adalah suatu suasana yang terdapat dalam suatu sekolah, yang menggambarkan keadaan sekolah yang riang karena terjadinya kepedulian antar sesama warga sekolah baik antara kepala sekolah, guru, dan peserta didik. Iklim kerja sangat mendukung keberhasilan tujuan guru yaitu keberhasilan proses pembelajaran. Iklim yang positif dirasakan oleh tenaga pendidik maka akan meningkatkan daya tahan seorang pendidik dalam menghadapi tekanan dalam melaksanakan tugasnya (Jati, 2017). Iklim kerja sekolah ialah komunikasi dan interaksi yang terjadi antara kepala sekolah dengan bawahannya atau sebaliknya, serta komunikasi dan iteraksi yang terjadi antar warga yang terdapat di dalam sekolah. Pramesti \& Muhyadi, (2018) menyatakan bahwa Supervisi kepala sekolah, motivasi kerja, iklim kerja guru dan status sosial ekonomi secara bersama-sama berpengaruh terhadap kinerja guru. Maka dapat disimpulkan bahwa, temuan yang didapat dari hasil penelitian ini dan diperkuat dengan hasil penelitian sebelumnya yaitu iklim kerja sekolah dapat mempengaruhi kinerja guru.

Temuan ketiga, berdasarkan taraf signifikansi 5\% ternyata hipotesis nol $\left(\mathrm{H}_{0}\right)$ yang menyatakan bahwa tidak terdapat kontribusi yang signifikan antara kepemimpinan kepala sekolah dan iklim kerja terhadap kinerja guru di SD Gugus II Tegallalang Tahun Ajaran 2020/2021 ditolak dan hipotesis alternatif $\left(H_{1}\right)$ dinyatakan diterima. Dengan demikian dapat ditarik simpulan bahwa terdapat kontribusi yang signifikan antara kepemimpinan kepala sekolah dan iklim kerja terhadap kinerja guru di SD Gugus II Tegallalang Tahun Ajaran 2020/2021. Secara bersama-sama koefisien korelasi kedua variabel kepemimpinan kepala sekolah dan iklim kerja terhadap kinerja guru sebesar 0,88 dan koefisien determinasinya sebesar 0,7744 . Ini berarti pula dapat diinterpretaikan bahwa kontribusi kedua variabel tersebut terhadap kinerja guru adalah sebesar $77,44 \%$. menurut Getruida (2020) menyatakan, Guru sangat berperan dalam mentransformasikan input pendidikan, maka daripada itu dapat dipastikan bahwa kualitas sekolah tidak akan meningkat tanpa adanya perubahan dan peningkatan kualitas guru. Maka darpada itu kinerja seorang guru harus dalam keadaan maksimal agar dapat melaksanakan tugas dan tanggung jawabnya dengan maksimal. Faktor yang dapat mempengaruhi kinerja guru adalah kepemimpinan kepala sekolah dan iklim kerja. Diperkuat dari hasil penelitain sebelumnya oleh Yulia (2013) menyatakan bahwa, ada pengaruh yang signifikan antara kepemimpinan kepala sekolah terhadap kinerja guru. Berdasarkan hasil penelitian menunjukkan bahwa ada pengaruh kepemimpinan kepala sekolah terhadap kinerja guru sebesar $15,1 \%$ sedangkan sisanya dipengaruhi faktor lain. Dapat disimpulkan bahwa dari hasil penelitian ini dan diperkuat dari hasil penelitian sebelumnya kepemimpinan kepala sekolah dan iklim kerja dapat mempengaruhi kinerja guru. Dimana menurut Wijania (2017), kinerja guru merupakan prestasi atau hasil guru untuk mencapai tujuan sekolah. Maka semakin baik kinerja guru dalam suatu sekolah akan meningkatkan kualitas mutu pendidikan di sekolah tersebut.

Berdasarkan hasil uji hipotesis tersebut maka dapat diinterpetasikan, jika kepemimpinan kepala sekolah dan iklim kerja di suatu sekolah baik maka akan mempengaruhi kinerja guru menjadi baik dalam suatu sekolah. Maka secara bersamasama terjadi hubungan yang signifikan antara kepemimpinan kepala sekolah dan iklim kerja terhadap kinerja guru di SD Gugus II Tegalalang tahun ajaran 2020/2021. 


\section{Simpulan}

Kinerja guru dipengeruhi oleh faktor kepemimpinan kepala sekolah dan iklim kerja. faktor tersebut akan membuat guru lebih nyaman dalam melaksanakan proses pembelajaran. Rasa nyaman guru akan meningkatakan kenja, sehingga guru dapat melakukan tugas dan tanggungjawabnya dengan baik. Hal ini tentunya akan berdampak terhadap kualitas pembelajaran yang dihasilkan.

\section{Daftar Pustaka}

Astuti, P., Indarti, S., \& Machasin, M. (2017). Pengaruh Kepemimpinan, Iklim Kerja Dan Beban Kerja Terhadap Kinerja Guru Pada Smp Negeri 3 Dumai. Jurnal Online Mahasiswa Fakultas Ekonomi Universitas Riau, 4(1), 1090-1104.

Hartini, Rahmawati, \& Asmin, E. A. (2021). Motivasi, Komitmen Organisasi, Kompetensi dan Dampaknya Terhadap Kinerja Guru. Jurnal Manajemen, 12(1), 52. https://doi.org/10.32832/jm-uika.v12i1.3950

Jamma, H. (2016). Hubungan Gaya Kepemimpinan Dan Kinerja Dengan Etos Kerja Guru Sekolah Dasar Di Kota Padang Panjang. Al-Fikrah: Jurnal Manajemen Pendidikan, 1(2), 149. https://doi.org/10.31958/jaf.v1i2.360

Junianto, D., \& Wagiran, W. (2013). Pengaruh kinerja mengajar guru, keterlibatan orang tua, aktualisasi diri dan motivasi berprestasi terhadap prestasi. Jurnal Pendidikan Vokasi, 3(3), 307-319. https://doi.org/10.21831/jpv.v3i3.1845

Kepala Sekolah, K., Akademik, S., Motivasi Kerja dalam Meningkatkan Kinerja Guru Hardono, dan, \& Yusuf, A. (2017). Educational Management Info Artikel. 26 Em, 6(1), 26-33.

Motivasi, D. A. N., Guru, K., \& Sekolah, D. I. (2017). Iklim, Kepuasan, Dan Motivasi Kerja Guru Di Sekolah Dasar Bpk Penabur. Jurnal Administrasi Pendidikan UPI, 24(1), 36-46. https://doi.org/10.17509/jap.v24i1.6509

Pramesti, D., \& Muhyadi. (2018). Faktor-faktor yang Mempengaruhi Kinerja Guru SMA. Harmoni Sosial, 5(1), 43-56. https://journal.uny.ac.id/index.php/hsjpi/article/view/11854/11411

Rachmawati, Y. (2013). Pengaruh Kepemimpinan Kepala Sekolah Terhadap Kinerja Guru. Al-Muaddib: Jurnal Ilmu-IImu Sosial \& Keislaman, 1(1), 19-28. https://doi.org/10.31604/muaddib.v1i1.108

Rahayu, S. (2017). Komunikasi Interpersonal Kepemimpinan Kepala Sekolah dan Budaya Kerja Organisasi terhadap Motivasi Kerja Dan Dampaknya pada Kepuasan Kerja Guru Sekolah Menengah Pertama. Manajemen Pendidikan, 12(1), 73. https://doi.org/10.23917/jmp.v12i1.2977

Ramadoni, W., Kusmintardjo, \& Arifin, I. (2016). Kepemimpinan Kepala Sekolah Dalam Upaya Peningkatan Kinerja Guru (Studi Multi Kasus Di Paud Islam Sabilillah Dan Sdn Tanjungsari 1 Kabupaten Sidoarjo). Jurnal Pendidikan (Teori Dan Praktik), 1(8), 1500-1504. https://doi.org/http://dx.doi.org/10.17977/jp.v1i8.6620

Sanders, M. G., Lukmansyah, D., Danniarti, R., \& Moh. Rois, Fartika Ifriqia, D. S. (2017). Jurnal Manajemen, Kepemimpinan, dan Supervisi Pendidikan Volume 1, No. 1, Juli-Desember 2017. American Journal of Education, 1(2), 233-255.

Setiyati, S. (2016). Pengaruh Kepemimpinan Kepala Sekolah Terhadap Motivasi Kerja dan Kinerja Guru. IImu Pendidikan: Jurnal Kajian Teori Dan Praktik Kependidikan, 1(2), 63-70. https://doi.org/10.17977/um027v1i22016p063

Silalahi, M. F., Daharnis, \& Alizamar. (2016). Pengaruh Iklim Organisasi Dan Kepuasan Kerja Terhadap Kinerja Guru. Jurnal Penelitian Pendidikan Indonesia, 2(1), 23-32. http://journal.um.ac.id/index.php/jptpp/article/view/6545/2792 
Sodik, M., Sahal, Y. F. D., \& Herlina, N. H. (2019). Pengaruh Kinerja Guru dalam Pelaksanaan Pembelajaran terhadap Prestasi Belajar Siswa pada Mata Pelajaran Alquran Hadis. Jurnal Penelitian Pendidikan Islam, 7(1), 97. https://doi.org/10.36667/jppi.v7i1.359

Subandi, S. (2018). Kontribusi Kepemimpinan Kepala Sekolah, Motivasi Kerja,dan Iklim Sekolah terhadap Kinerja Guru. Jurnal Penelitian Dan Pengembangan Sains Dan Humaniora, 1(2), 57-63. https://doi.org/10.23887/jppsh.v1i2.12934

Sugiarta, M. P., Dantes, N., \& Natajaya, N. (2018). Determinasi Sikap Guru terhadap Profesinya, Konsep Diri, dan Iklim Kerja Sekolah terhadap Kinerja Guru Sekolah Dasar. Jurnal Penelitian Dan Pengembangan Sains Dan Humaniora, 1(1). https://doi.org/10.23887/jppsh.v1i1.12926

Sukardi. (2012). Metodologi Penelitian Pendidikan. PT Bumi Aksara.

Verawati Wote, A. Y., \& Patalatu, J. S. (2019). Pengaruh Gaya Kepemimpinan Transformasional dan Kepuasan Kerja terhadap Kinerja Guru Sekolah Dasar. Jurnal IImiah Sekolah Dasar, 3(4), 465. https://doi.org/10.23887/jisd.v3i4.21782

Wijania, I. W. (2017). Kontribusi Kepemimpinan Pelayan Kepala Sekolah, Motivasi Kerja Dan Disiplin Kerja Terhadap Kinerja Guru. Jurnal IImiah Pendidikan Dan Pembelajaran, 1(4), 176-184. https://ejournal.undiksha.ac.id/index.php/JIPP/article/download/11983/7646

Yustiyawan, R. H., Supriyanto, A., \& Mustiningsih. (2016). Hubungan Pengembangan Karir, Kompetensi Profesional, Dan Motivasi Kerja Dengan Kinerja Guru Paud Di Kecamatan Driyorejo Kabupaten Gresik. Jurnal Pendidikan: Teori, Peneltian Dan Pengembangan, 1(7), 1297-1304. http://journal.um.ac.id/index.php/jptpp/article/view/6545/2792 